\title{
CONTRIBUTIONS TOWARDS A KNOWLEDGE OF THE COLEOPTERA OF AUSTRALIA.
}

\author{
By A. Sidney Olliff, F.E.S., \\ Assistant Zoologist, Australian Museum.
}

No. VI.-New LAMELLICORNIA AND LONGICORNIA.

In this paper I have described a few new species which seem to me worth making known from a systematic point of view, either for their individual characteristics, or for geographical reasons. All of them-including the one for which I venture to propose a new genus-have been submitted to my friend Mr. H. W. Bates, who, with his usual kindness, has given me the benefit of his great experience in deciding the position of the more puzzling forms.

\section{LAMELLICORNIA.}

Othnonius, gen.nov. (Macrophyllina).

Head rather small; clypeus broad, somewhat concave, nearly semicircular in front, the margin strongly raised, the face beyond the margin sloping almost perpendicularly to the labrum. Labrum prominent and articulated, rather strongly triangularly emarginate in front, with the front angles and sides rounded. Maxillæ short, robust; the inner lobe very narrow ; the outer with three irregular rather blunt teeth on the inner margin near the apex. Maxillary palpi with the 1st joint very small, the 2nd and 3rd subtriangular, of nearly equal size, 4 th about as long as the three preceding joints together, somewhat narrowed at both extremities. Labium broad, slightly concave, abruptly narrowed at the point of insertion of the palpi, rounded in front. Labial palpi flattened laterally, the 
basal joint very small, the 2nd much larger, subtriangular, the 3rd obovate, a little larger than the third. Mandibles solid, horny, and rather sharp at the extremity. Antennæ short, robust, 10 -jointed, the club composed of six very long lamellæ which are rather strongly curved outwardly towards the apex; the basal joint short, robust, 2 nd about half as long as the 1st, rounded in front, 3rd about twice as long as the 2 nd, rather broader in front than behind, 4th short, irregularly triangular, and produced into an angular point externally. Prothorax transverse; anterior margin straight; feebly bisinuate at the base. Scutellum large, rounded behind. Elytra subovate, strongly convex, broader at the base than the prothorax; each with a distinct sutural stria and four pairs of rather obscure strix which are effaced posteriorly. Pygidium perpendicular. Legs rather long; anterior tibiæ strongly tridentate; slightly incurved, with the apical spine narrow and acute; the intermediate and posterior tibiæ nearly straight, the former a little, and the latter considerably, thickened at the apex, each with a feeble external carina about the middle and an inconspicuous dentation between this and the base; the tarsi longer than the tibiæ; the claws strongly dentate at the base.

This very distinct genus appears to belong to Lacordaire's subtribe Macrophyllides, which is chiefly composed of African forms. It has solid horny mandibles, strong toothed maxillæ, prominent and articulated labrum, and distinct ventral segments to the abdomen - all characters approximating it to Macrophylla and the allied Holophylla; but the form of the antennæ, with their sixjointed club, and the structure of the legs-particularly of the claws-will, I believe, suffice to distinguish it from any genus at present recorded.

\section{Othnonius Batesis, sp.n.}

Elongate-ovate, rather strongly convex, somewhat shining; head, prothorax, scutellum, pygidium and legs piceous; antennæ testaceous, except the first two joints which are reddish brown; elytra reddish castaneous. 
Head finely and moderately closely rugulose-punctate at the base, sparingly punctured in front, almost impunctate in the middle. Prothorax broadly transverse, the punctuation strong and moderately close, inclining to rugosity near the anterior margin; the sides moderately strongly reflexed, nearly straight for rather more than one half their length, then obliquely narrowed to the anterior margin. Scutellum sparingly and not very strongly punctured. Elytra nearly twice as long as the head and prothorax together, moderately strongly rugulose-punctate, with the two lateral pairs of striæ indistinct, and the interstices broad, the first (that between the suture and the first pair of striæ) very broad at the base and narrowed posteriorly; the shoulders somewhat prominent. Beneath the sterna are thickly clothed with long decumbent grey pubescence; the abdomen pitchy, and very finely punctured, the sides and the dorsal surface reddish. Length $16-18 \mathrm{~mm}$.

Wilcannia, Mossgiel, Walgett, and Clarence River, N. S. Wales.

This species is occasionally found in vast numbers in the dry plain country in the Western division of the colony, flying by day, and usually in the hot sunshine. All the specimens which have come under my observation appear to belong to one sexpresumably the male-as they present no differences in size or structure.

\section{LONGICORNIA.}

\section{Nothophysis Barnardi, sp.n.}

Elongate, sub-parallel, reddish castaneous, somewhat shining; sparingly clothed with fine yellowish pubescence; antennæ very robust, thickly clothed with fine yellowish pubescence; head and prothorax strongly and sparingly punctured; elytra very strongly and moderately closely punctured above, less strongly and more closely punctured near the sides, with the costæ indistinct.

Head more strongly punctured between the eyes than in front or behind, with an abbreviated median line; mandibles very 
prominent, incurved, strongly and sparingly punctured. Antennæ about as long as the prothorax and elytra together, robust, somewhat flattened; the third joint nearly as long as the first, the succeeding joints slightly increasing in length towards the apex, the terminal one longer and a trifle narrower than the rest. Prothorax broadly transverse, slightly narrower in front than behind, strongly, irregularly, and sparingly punctured on the disc, a little more strongly and closely punctured near the posterior angles; anterior margin gently sinuate on each side; the sides rather strongly reflexed and strongly produced just before the middle, narrowed obliquely both before and behind this production; the posterior margin feebly bisinuate. Scutellum rounded behind, rather strongly punctured. Elytra at the base broader than the prothorax, parallel-sided, arcuately rounded posteriorly, very strongly, irregularly, and not very closely punctured on the disc, the punctuation inclining to rugosity beyond the middle and near the sides; each with two very indistinct costæ on the disc which are entirely effaced about three-fourths from the base ; the suture somewhat raised. Underside moderately thickly covered with fine testaceous pubescence; abdominal segments finely punctured. Legs thickly clothed with reddish-yellow pubescence, rather closely punctured; the spongy undersurface of the first three joints of the tarsi testaceous. Length $17-20 \mathrm{~mm}$.

Duaringa, Dawson River, Queensland (G. Barnard).

Allied to Nothophysis lucanoides, Serv., from South Australia, but distinguished by its more convex and rather more strongly punctured elytra (of which the costæ are less strongly raised), and by the greater space between the eyes.

\section{Monohammus aestheticus, sp.n.}

Elongate, densely covered with umber-brown pile, head with a distinct median line, somewhat impressed between the antennæ; prothorax with the lateral spines prominent and acute, strongly and sparingly punctured on the disc on either side of the middle ; 
elytra moderately strongly and sparingly punctured for the basal two-thirds, scarcely punctate posteriorly.

Head impunctate. Antennæ in both sexes more than twice as long as the body, rather closely pubescent, gradually attenuated towards the extremity; the first joint very robust, and thickened towards the apex, where it is somewhat produced outwardly and obliquely cut off above; 2 nd joint more than one and a-half times as long as the first; apical joint about as long as the two preceding joints together. Prothorax transverse, with two impressed lines near the anterior margin, and two near the posterior margin, the former interrupted in the middle, the punctuation confined to the disc on either side of the middle. Scutellum rounded behind, impunctate. Elytra considerably narrowed posteriorly, rounded at the apex, sparingly and moderately strongly punctured near the base, the punctuation gradually decreasing in strength posteriorly, effaced beyond the basal two-thirds. Underside densely clothed with umber-brown pubescence like the upper surface, except the head, prosternum, and the inner side of the anterior femora, which are pitchy and scantily furnished with fine grey pubescence. Legs with the femora rather closely pubescent, the pubescence inclining to grey above; tibiæ with dense outstanding pile towards the apex. Length, ơ $29 \mathrm{~mm}$; ㅇ $32 \mathrm{~mm}$.

Cloncurry, Queensland.

A very fine and distinct species quite unlike any of those known to me, but evidently belonging to the Monohammus fistulator group. The sexes only appear to differ in the length of the antennæ, those of the male being somewhat longer than those of the other sex.

\section{Monohammus artius, sp.n.}

Elongate-ovate, densely covered with ashy-grey pubescence; head with a few scattered punctures in front between the antennæ, and a few on each side of the median line behind the eyes ; prothorax with the lateral spines strongly produced, rather blunt; elytra sparingly punctured throughout. 
Antennæ densely pubescent, in the male about one and a-half times as long as the body ; 1 st joint enlarged, similar in form to that of the preceding species, but not so much produced outwardly at the apex. Prothorax transverse, a few scattered punctures on either side of the middle, with two anterior and two posterior transverse impressed lines, the two former interrupted in the middle, and all, except that nearest the posterior margin, somewhat obscure. Scutellum rounded behind, impunctate. Elytra considerably narrowed behind, rounded at the apex, the punctuation gradually decreasing in strength posteriorly. Underside and legs strongly pubescent. Length, ô $21 \mathrm{~mm}$. ; ᄋ $24 \mathrm{~mm}$.

Cape York (Powell), Duaringa (G. Barnard), Queensland.

This species belongs to the group of the genus in which the antennæ do not exceed the length of the body by more than about one half its length. It is most nearly allied to $M$. argentatus, Hope, but it has not the same silky appearance, and the antennæ are more densely pubescent. The head is also much less punctured behind the eyes, and the lateral spines on the prothorax are less prominent.

Rhytiphora Rosei, sp.n.

Elongate, nearly parallel-sided, piceous, very densely clothed with silvery-grey, almost white, pile; prothorax with transverse bands of pile ; elytra irrorated with black and white.

Head piceous, irregularly and not very closely punctured, rugulose between the eyes; the face, a narrow circle round the eyes, and an oblique stripe on each side, silvery-white; median line distinct. Antennæ a little longer than the body, each joint (except the basal, which is wholly piceous) thickly clothed with silvery-grey pubescence at the base, and with black pubescence at the apex, the grey pile decreasing in extent, joint by joint, towards the apex. Prothorax piceous, rather strongly transversely strigose, with a few punctures on the disc, banded transversely with silvery-grey, the sides wholly grey. Scutellum elongate, rounded behind, inconspicuously punctured. Elytra very convex, the apex rounded, with a few large irregular 
tubercles near the base; the silvery-grey pile arranged in irregular longitudinal lines, the intervals exposing the piceous derm often confluent, and forming irregular oblique lines; near the apex, and near the suture behind the middle, the pile is only ornamented with minute spot-like interruptions. Underside thickly clothed with silvery-grey pile, the second and third abdominal segments densely covered with ochreous pile. Legs rather robust, densely pilose, the innerside of the anterior tibiæ piceous. Length $32 \mathrm{~mm}$.

Coonamble, New South Wales (J. H. Rose).

A beautiful species, perhaps most nearly allied to Rhytiphora cretata, Pasc., but quite unlike any known form in colour and marking.

NOTES AND EXHIBITS.

Mr. Skuse exhibited fine specimens of the following gigantic Tipulidæ-Semnotes imperatoria, Westw., and Semnotes ducalis, Westw., both of which species are now known to occur in the vicinity of Sydney, the former having been taken by Mr. G. Masters, at Lane Cove, and the latter recently by Mr. H. Prince, at Fairy Bower, near Manly: and a very distinct undescribed species of Leptotarsus, Guérin, captured by Mr. Prince last September, at Lawson, Blue Mountains, which for length of limb is the largest of known Australian Diptera.

Mr. Froggatt exhibited a collection of beetles belonging to the genus Paropsis, amounting to about 33 species. The specimens were recently collected by Mr. Baeuerlen in the neighbourhood of Mount Dromedary, N.S.W. 


\section{$2 \mathrm{BHL}$ Biodiversity Heritage Library}

Olliff, Arthur Sidney. 1890. "Contributions towards a knowledge of the Coleoptera of Australia." Proceedings of the Linnean Society of New South Wales 5, 5-11. https://doi.org/10.5962/bhl.part.18620.

View This Item Online: https://www.biodiversitylibrary.org/item/22899

DOI: https://doi.org/10.5962/bhl.part.18620

Permalink: https://www.biodiversitylibrary.org/partpdf/18620

\section{Holding Institution}

MBLWHOI Library

\section{Sponsored by}

MBLWHOI Library

\section{Copyright \& Reuse}

Copyright Status: NOT_IN_COPYRIGHT

This document was created from content at the Biodiversity Heritage Library, the world's largest open access digital library for biodiversity literature and archives. Visit BHL at https://www.biodiversitylibrary.org. 